\title{
Calcium lonophore, Phorbol Ester, and Chemotactic Peptide-induced Cytoskeleton Reorganization in Human Neutrophils
}

\author{
Thomas H. Howard and Danher Wang \\ Department of Pediatrics, University of Virginia, Charlottesville, Virginia and Department of Cell \\ Biology and Anatomy, University of Alabama at Birmingham, Birmingham, Alabama 35294
}

\begin{abstract}
Formyl-methionylleucylphenylalanine ( $f$ MLP) activation of neutrophils causes an increase in intracellular $\mathrm{Ca}^{2+}$, activation of protein kinase $\mathrm{C}$ and an increase in $\mathrm{F}$-actin content. To examine the role of $\mathrm{Ca}^{2+}$ and protein kinase $\mathrm{C}$ activation as determinants of change in F-actin content of neutrophils, we used the NBDphallacidin extraction assay to compare the kinetics and extent of change in F-actin content of cells activated with $f$ MLP, the calcium ionophore A23187 or phorbol myristate acetate (PMA). All stimuli increase the F-actin content in a dose-dependent manner, however, the rate of increase is slower and the maximum F-actin content is less for calcium ionophore and PMA than for $f M L P$-activated cells. The A23187-induced increase in F-actin content, but not that of $f$ MLP, depends upon external free $\left[\mathrm{Ca}^{2+}\right]$. In A23187-activated cells, F-actin content increases at $\left[\mathrm{Ca}^{2+}\right]_{\text {free }}$ $\geq 5 \mu \mathrm{M}$, is maximal at $\left[\mathrm{Ca}^{2+}\right]_{\text {free }} \geq 10 \mu \mathrm{M}$ and is negligible at physiologic free $\left[\mathrm{Ca}^{2+}\right]\left(1^{-7}-10^{-6} \mathrm{M}\right)$. Combinations of PMA with $A 23187$ or $f$ MLP inhibit the A23187, but not the $f$ MLP, activated actin polymerization. Comparison and combination of these activators shows that neither $\mathrm{Ca}^{2+}$-dependent activation with A23187 nor activation with PMA alone or in combination mimic the $f$ MLP-induced changes in cytoskeleton organization of neutrophils.
\end{abstract}

\section{Introduction}

Chemotaxis, chemokinesis, and locomotion of human neutrophils require continuous assembly, disassembly and reorientation of the cytoskeleton. Dynamic modulation of the cytoskeleton is directed by the location and concentration of soluble chemotactic factors that include a variety of derivatized plasma and bacterial proteins $(1,2)$. The best characterized cytoskeletal alterations are those associated with binding of formyl-methionylleucylphenylalanine ( $f$ MLP), ${ }^{1}$ a chemotactic peptide (3-5). Activation of neutrophils with $f$ MLP results in rapid polymerization of actin followed by a slower depolymerization and redistribution

Address reprint requests to Dr. Howard, Children's Hospital of Alabama, Pediatric Hematology, 16007 th Avenue South, Suite 651, Birmingham, AL 35233.

Received for publication 31 January 1986 and in revised form 26 December 1986.

1. Abbreviations used in this paper: H/HBSS, Hanks'/Hepes balanced salt solution; $f$ MLP, formylmethionylleucyl phenylalanine; MOPS 3[ $N$-morpholino]propanesulfonic acid; NBD-phallacidin, nitrobenzo-oxadiazole phallacidin; PMA, phorbol myristate acetate; RFI, relative fluorescence intensity.

J. Clin. Invest.

(C) The American Society for Clinical Investigation, Inc. 0021-9738/87/05/1359/06 $\$ 1.00$

Volume 79, May 1987, 1359-1364 of F-actin within the cell (4-6). The exact mechanism whereby $f$ MLP alters F-actin content and distribution in neutrophils is not understood. Like many receptor-ligand interactions, however, binding of $f$ MLP to its receptor induces hydrolysis of polyphosphatidylinositides (7-10), release of intracellular calcium $(11,12)$, activation of protein kinase $C(13-15)$, and metabolism of arachidonic acid (16). Both protein kinase $\mathrm{C}$ activation and a rapid rise in intracellular calcium to micromolar concentrations occur coincidentally with the initiation of actin polymerization and precede the time of maximal F-actin content in neutrophils (17).

Temporal interposition of the calcium rise and protein kinase activation between receptor occupancy and maximal F-actin content suggests that one or both may be required for initiation and/or termination of the changes in F-actin content. This hypothesis is strengthened by the observation that neutrophils contain gelsolin, a calcium-dependent, actin regulatory protein, and that the kinetics of in vitro actin polymerization vary with free calcium concentration (18-24). To determine whether an increase in intracellular calcium concentration or protein kinase $\mathrm{C}$ activation alone can explain the $f$ MLP-induced cytoskeletal reorganization, we compared the $f$ MLP-induced changes in Factin content to those induced by the calcium ionophore A23187 and a protein kinase $\mathrm{C}$ activator, phorbol myristate acetate (PMA) $(25,26)$. The studies suggest that neither protein kinase $\mathrm{C}$ activation nor increase in intracellular calcium alone or in combination are sufficient to explain the $f$ MLP-induced changes in cytoskeletal organization. The A23187 activation of neutrophils causes significant changes in $\mathrm{F}$-actin content; however, the required free calcium concentration is much higher than the free calcium concentrations reported in $f$ MLP-activated cells. Activation of cells with PMA blocks the A23187-induced changes in F-actin content.

\section{Methods}

Materials. A23187 (Calbiochem Behring Corp., La Jolla, CA); phorbol myristate acetate; $f$ MLP, MOPS (3-[ $N$-morpholino]propanesulfonic acid), Hepes, EGTA, and $\mathrm{CaCO}_{3}$ (Sigma Chemical Co., St. Louis, MO); NBD-phallacidin (Molecular Probes, Junction City, OR).

Preparation of neutrophils. Leukocytes were prepared from human peripheral blood in EDTA anticoagulant by Dextran 60 (Cutter Laboratories, Berkeley, CA) sedimentation. Contaminating erythrocytes were lysed with $0.83 \%$ ammonium chloride. Neutrophils were purified on Ficoll-Hypaque gradients, yielding $96-97 \%$ neutrophils, $2-3 \%$ eosinophils, $0-1 \%$ mononuclear cells (27). All experiments were done in Hanks' balanced salt solution or MOPS buffer within $5.5 \mathrm{~h}$ after the blood sample was obtained.

Quantification of F-actin content. F-actin content was determined by the NBD-phallacidin (nitrobenzo-oxadiazole phallacidin) extraction assay described by Howard et al. (6). Briefly, the relative fluorescence intensity (RFI) of methanol extracts from cells exposed to either control solvent dimethylsulfoxide (DMSO) $(0.05 \mathrm{vol} \%)$ or activator in DMSO was determined by fluorometry (excite $465 \mathrm{~nm}$; emit $535 \mathrm{~nm}$ ). Relative F-actin content is expressed as RFI of test cells at specified time/RFI of DMSO 
sample at $0 \mathrm{~s}$. All experiments were done at $25^{\circ} \mathrm{C}$. All experiments were done in Hanks'/Hepes balanced salt solution (H/HBSS) (25 mM Hepes, $50 \mathrm{mM}$ phosphate, $150 \mathrm{mM} \mathrm{NaCl}, 4 \mathrm{mM} \mathrm{KCl}, 1.0 \mathrm{mM} \mathrm{MgCl}$ ) except those with controlled external free calcium concentration $\left(\left[\mathrm{Ca}^{2+}\right]_{\text {free }}\right)$.

Preparation of $\left[\mathrm{Ca}^{2+}\right]_{\text {ree }}$ buffers. Buffers utilized to control external free $\left[\mathrm{Ca}^{2+}\right]\left(\left[\mathrm{Ca}^{2+}\right]_{\text {free }}\right)$ were prepared according to a previously utilized (28) computer program that considers Fabiato's constants (29) for $\mathrm{Ca}^{2+}$ binding to EGTA, $\mathrm{Mg}^{2+}$ concentration, ionic strength, pH, EGTA concentration, $\mathrm{Ca}^{2+}$ stock concentration. The $\mathrm{Ca}^{2+}$ stock was prepared by reacting and solubilizing known dry weights of anhydrous $\mathrm{CaCO}_{3}$ with concentrated $\mathrm{HCl}$ and diluting in deionized $(<2 \mu \mathrm{ohms})$ doubly distilled water. Results did not vary with EGTA or $\mathrm{Ca}^{2+}$ stock since the minimal $\left[\mathrm{Ca}^{2+}\right]_{\text {free }}$ necessary for any significant A23187-induced increase in $\mathrm{F}$. actin content was $\geq 5 \mu \mathrm{M}$ with each of four different stocks tested. Final composition of MOPS buffer was $2.0 \mathrm{mM}$ MOPS, $4.5 \mathrm{mM} \mathrm{KCl}, 140 \mathrm{M}$ $\mathrm{NaCl}, 1.2 \mathrm{mM}$ phosphate, $1.2 \mathrm{mM} \mathrm{MgCl}, 1.0 \mathrm{mM}$ EGTA at $\mathrm{pH} 7.15$ ionic strength 150 and free calcium of $10^{-7}-10^{-5} \mathrm{M}$. Varied $\left[\mathrm{Ca}^{2+}\right]_{\text {free }}$ was controlled by addition of varied volumes of $0.1 \mathrm{M} \mathrm{Ca}^{2+}$ stock to MOPS buffer. The $\left[\mathrm{Ca}^{2+}\right]_{\text {free }}$ buffers were prepared fresh daily and were tested initially, and subsequently at intervals, with a $\mathrm{Ca}^{2+}$ electrode to assure accuracy of $\left[\mathrm{Ca}^{2+}\right]_{\text {free }}$. For experiments in MOPS buffer, cells were prepared in buffer with no $\mathrm{Ca}^{2+}$ added and then resuspended in MOPS buffer with known $\left[\mathrm{Ca}^{2+}\right]_{\text {froe }}$. Experiments were initiated by addition of indicated concentrations of A23187 at zero time. Presence or absence of $\mathrm{MgCl}_{2}$ in MOPS buffer did not affect the rate or extent of actin polymerization since experiments in MOPS buffer with or without $\mathrm{MgCl}_{2}$ yielded identical values for $\mathrm{F}$-actin content.

\section{Results}

Effect of $\mathrm{Ca}^{2+}$ ionophore, PMA, and fMLP on F-actin content. Several neutrophil responses, including change in cytoskeletonassociated actin are induced by $f$ MLP, A23187, and PMA (19, 20). The time course of changes in F-actin content are described in Fig. 1 and Table I. In these studies, Ficoll-Hypaque purified

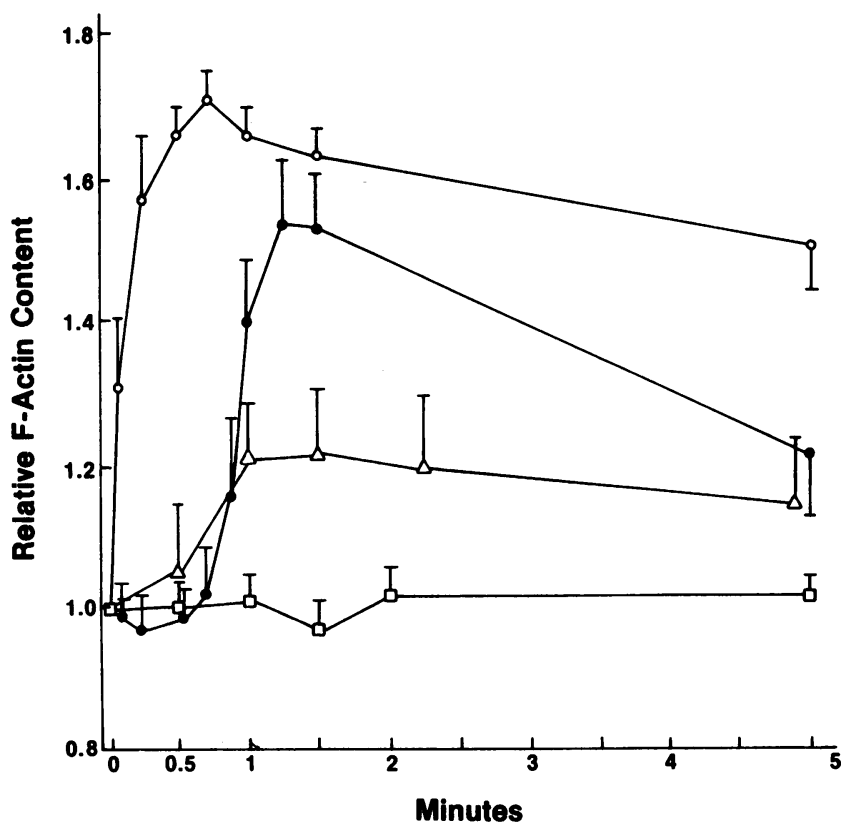

Figure 1. Time course of F-actin content in neutrophils activated with fMLP, A23187, and PMA. At time zero neutrophils in H/HBSS (total $\left[\mathrm{Ca}^{2+}\right]=1.0 \mathrm{mM}$, free $\left.\left[\mathrm{Ca}^{2+}\right]>10^{-5} \mathrm{M}\right)$ were exposed to control solvent DMSO (0.05 vol\%) (-口-), $0.5 \mu \mathrm{M} f \mathrm{MLP}($ (一一), $1 \mu \mathrm{M}$ A23187 (- - -), or $1 \mu \mathrm{M}$ PMA $(-\Delta-)$ at $25^{\circ} \mathrm{C}$ and relative F-actin content was determined at indicated times. Results shown are mean \pm SD from five trials at each time.
Table I. Comparison of Kinetics and Extent of Change in F-actin after $f M L P, \mathrm{Ca}^{2+}$ Ionophore, or PMA Activation

\begin{tabular}{lll}
\hline & Rate of polymerization & Maximum relative F-actin \\
\hline & $(\%$ F-actin $) / s^{*}$ & \\
$0.5 \mu \mathrm{M} f \mathrm{MLP}$ & $3.80 \pm 0.60$ & $1.72 \pm 0.05$ \\
$1.0 \mu \mathrm{M} \mathrm{A23187^{ \ddagger }}$ & $1.50 \pm 0.10^{8}$ & $1.54 \pm 0.08^{\S}$ \\
$1.0 \mu \mathrm{M}$ PMA & $0.37 \pm 0.19^{8}$ & $1.22 \pm 0.11^{8}$
\end{tabular}

* In $\mathrm{Ca}^{2+}$ ionophore experiments, the total calcium concentration of the buffer was $1.0 \mathrm{mM}$.

${ }^{\ddagger}$ Rate of polymerization is expressed as percent increase in F-actin content/second determined between 0 and $20 \mathrm{~s}$ for $f$ MLP; $40-75 \mathrm{~s}$ for A23187; 0-60 s for PMA. Values are \pm 1 SD from five trials.

${ }^{5} P<0.01$ when compared with $0.5 \mu \mathrm{M} f \mathrm{MLP}$.

cells in Hanks'/Hepes buffer containing $1 \mathrm{mM}$ total calcium concentration were activated at the zero time with $0.5 \mu \mathrm{M} f \mathrm{MLP}$, $1 \mu \mathrm{M}$ A23187 or $1 \mu \mathrm{M}$ PMA and the F-actin content was determined at the indicated times after activation. All activators cause an increase followed by a decrease in F-actin content. The maximum extent of $f$ MLP-induced change in F-actin content is significantly greater than that caused by A23187 or PMA ( $P$ $>0.01$ ). The time to maximal F-actin content with $f$ MLP is shorter than that with calcium ionophore or PMA.

The rate of actin polymerization in $f$ MLP-, calcium ionophore-, and PMA-activated cells is also different. As shown in Table I, at $25^{\circ} \mathrm{C}$ the mean rate of $f$ MLP-induced actin polymerization (3.80\% increase in F-actin content/s) is greater than the mean rate of polymerization in A23187-activated (1.50\%) or PMA-activated $(0.37 \%)$ cells. The rate of depolymerization is similar for A23187 and $f$ MLP-activated neutrophils (9-12\% and 6-10\% decrease in F-actin content per minute, respectively).

Effect of activator dose on F-actin content. The dose response for $f$ MLP-induced F-actin content is known (3-5). F-actin content is maximal for $f$ MLP concentrations $>0.01 \mu \mathrm{M}$. Fig. 2 shows the effect of increasing concentrations of A23187 and

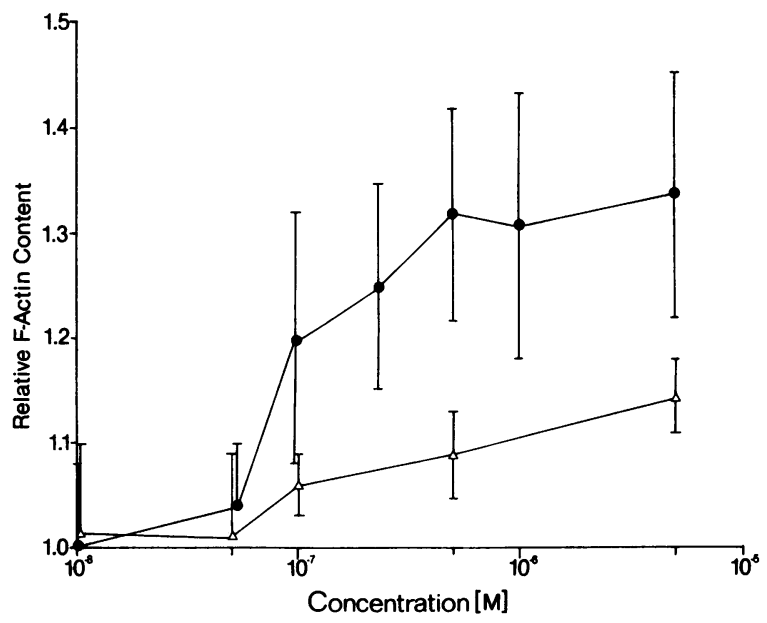

Figure 2. Effect of concentration of A23187 and PMA on maximum F-actin content of neutrophils. Neutrophils in $\mathrm{H} / \mathrm{HBSS}\left(\left[\mathrm{Ca}^{2+}\right]_{\text {rotal }}\right.$ $\left.=1.0 \mathrm{mM},\left[\mathrm{Ca}^{2+}\right]_{\text {free }}>10^{-5} \mathrm{M}\right)$ were exposed to increasing concentrations of A23187 (- - ) or PMA (- - ) at $25^{\circ} \mathrm{C}$ for $1.5 \mathrm{~min}$. The relative $\mathrm{F}$-actin content was determined at $1.5 \mathrm{~min}$. Shown are mean \pm SD from five trials. 
PMA on F-actin content of neutrophils. F-actin content is maximal for A23187 concentrations $\geq 0.5 \mu \mathrm{M}$ and for PMA concentrations $\geq 0.1 \mu \mathrm{M}$. Unlike $f$ MLP and A23187 the PMA effect does not reach saturation and the concentrations required for even minimal change in F-actin content are massive when compared to PMA concentrations required for functional responses such as superoxide production (30).

Effect of $\mathrm{Ca}^{2+}$ on A23187 and fMLP-induced change in $\mathrm{F}$ actin content. The actin polymerization observed with A23187 activation requires the presence of external calcium; $f$ MLP-induced increase in F-actin content is independent of external calcium concentration. As shown in Fig. 3, neutrophils exposed to $1 \mu \mathrm{M}$ A23187 or $0.5 \mu \mathrm{M} f \mathrm{MLP}$ in the presence of $1 \mathrm{mM}$ $\left[\mathrm{Ca}^{2+}\right]_{\text {total }}$ increase $\mathrm{F}$-actin content $1.5 \mathrm{~min}$ after addition of activator. Addition of $3 \mathrm{mM}$ EGTA prior to addition of A23187, inhibits the A23187-induced but not the $f$ MLP-induced increase in F-actin content. DMSO ( $0.05 \mathrm{vol} \%)$, the solvent for both activators, does not alter F-actin content of cells after $1.5 \mathrm{~min}$ in the presence or absence of free calcium. Cells incubated in buffer with $3 \mathrm{mM}$ EGTA for as long as $3 \mathrm{~h}$, retain the ability to polymerize actin in response to $f$ MLP activation (data not shown). These results show that external calcium is required for A23187induced actin polymerization and raise the question of whether the external calcium concentration required for A23187-induced actin polymerization is physiologically relevant.

To study the effect of $\left[\mathrm{Ca}^{2+}\right]$ on F-actin content in A23187 activated cells we determined the effect of varied external $\left[\mathrm{Ca}^{2+}\right]_{\text {free }}$ on the F-actin content of A23187-activated neutrophils. Cells in MOPS buffer with varied external $\left[\mathrm{Ca}^{2+}\right]_{\text {free }}$ were activated by addition of $1 \mu \mathrm{M} \mathrm{A23187}$ and F-actin content was determined at increasing times after A23187 addition. As shown in Fig. 4, no significant increase in F-actin content is observed when $\left[\mathrm{Ca}^{2+}\right]_{\text {free }}$ is $<5 \mu \mathrm{M}$. A minimal increase is observed in the presence of $5 \mu \mathrm{M}\left[\mathrm{Ca}^{2+}\right]_{\text {free }}$. An initial decline in F-actin content at $5 \mathrm{~s}$ is noted and is maximal for $10 \mu \mathrm{M}\left[\mathrm{Ca}^{2+}\right]_{\text {free }}$. At all $\left[\mathrm{Ca}^{2+}\right]_{\text {free }}$, the $\mathrm{F}$-actin content was maximal at 1 or $1.5 \mathrm{~min}$ after $\mathrm{A} 23187$ addition.

Fig. 5 shows the $\left[\mathrm{Ca}^{2+}\right]_{\text {free }}$ dose response of F-actin content in A23187-activated cells at $5 \mathrm{~s}, 1 \mathrm{~min}$, and $1.5 \mathrm{~min}$. The modest decrease in $\mathrm{F}$-actin content at $5 \mathrm{~s}$ is statistically insignificant. The minimum $\left[\mathrm{Ca}^{2+}\right]_{\text {free }}$ that causes a modest, significant increase in F-actin content is $5 \mu \mathrm{M}$. This free calcium concentration is greater than the reported intracellular $\left[\mathrm{Ca}^{2+}\right]_{\text {free }}$ in $f$ MLP-activated cells $(11,12,21)$ and the maximum extent of change in

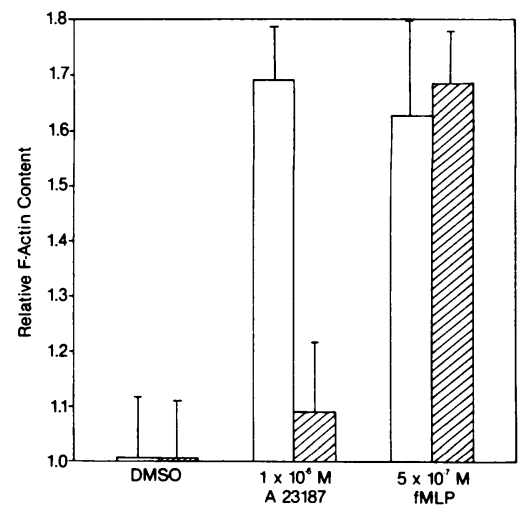

Figure 3. Effect of external calcium concentration on F-actin content of A23187 and $f$ MLPactivated neutrophils. Cells were exposed to DMSO (0.05 vol\%), 1

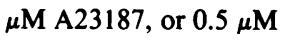
$f$ MLP for $1.5 \mathrm{~min}$ at $25^{\circ} \mathrm{C}$ in the presence of $1 \mathrm{mM}\left[\mathrm{Ca}^{2+}\right]_{\text {total }}$ or 1 $\mathrm{mM}\left[\mathrm{Ca}^{2+}\right]_{\text {total }}$ plus 3 mM EGTA. The relative F-actin content was determined. Results shown are mean \pm SD for five trials.

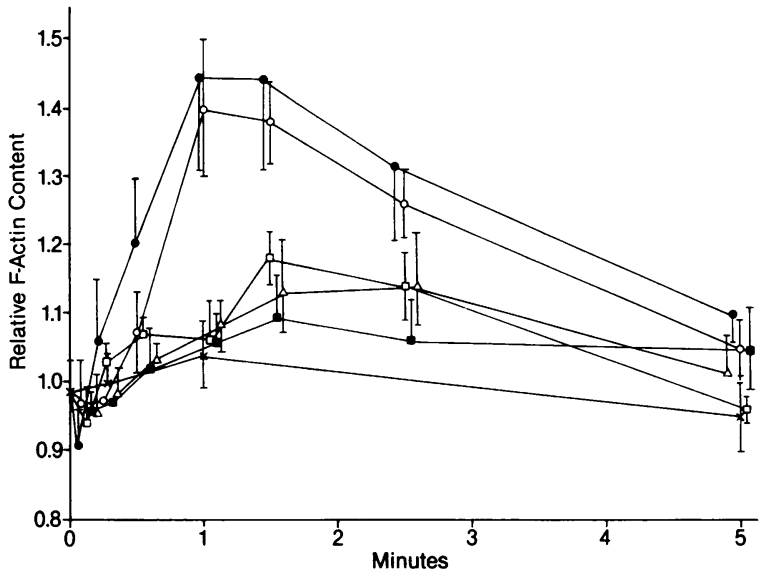

Figure 4. Time course of F-actin content in A23187-activated neutrophils at varied $\left[\mathrm{Ca}^{2+}\right]_{\text {free }}$. At zero time, cells were exposed to DMSO $(0.05 \mathrm{vol} \%)(-\times-)$ or $1 \mu \mathrm{M}$ A23187 in MOPS buffer with $\left[\mathrm{Ca}^{2+}\right]_{\text {free }}$ of $0.1 \mu \mathrm{M}(-\square-), 1 \mu \mathrm{M}(-\Delta-), 5 \mu \mathrm{M}(-\square-), 10 \mu \mathrm{M}(-\bullet-)$ or $>10 \mu \mathrm{M}(-0-)$ and relative F-actin content was determined at indicated times. Results are mean $\pm \mathrm{SD}$ from five trials.

F-actin content of $f$ MLP-activated cells is in excess of that induced by any $\left[\mathrm{Ca}^{2+}\right]_{\text {free }}<10 \mu \mathrm{M}$.

Effect of combining A23187 and PMA on F-actin content of neutrophils. Since neither A23187 nor PMA mimic the effect of $f$ MLP on F-actin content of neutrophils and since these activators can modulate the effect of each other on superoxide production $(35,36)$, we investigated the effect of combining A23187

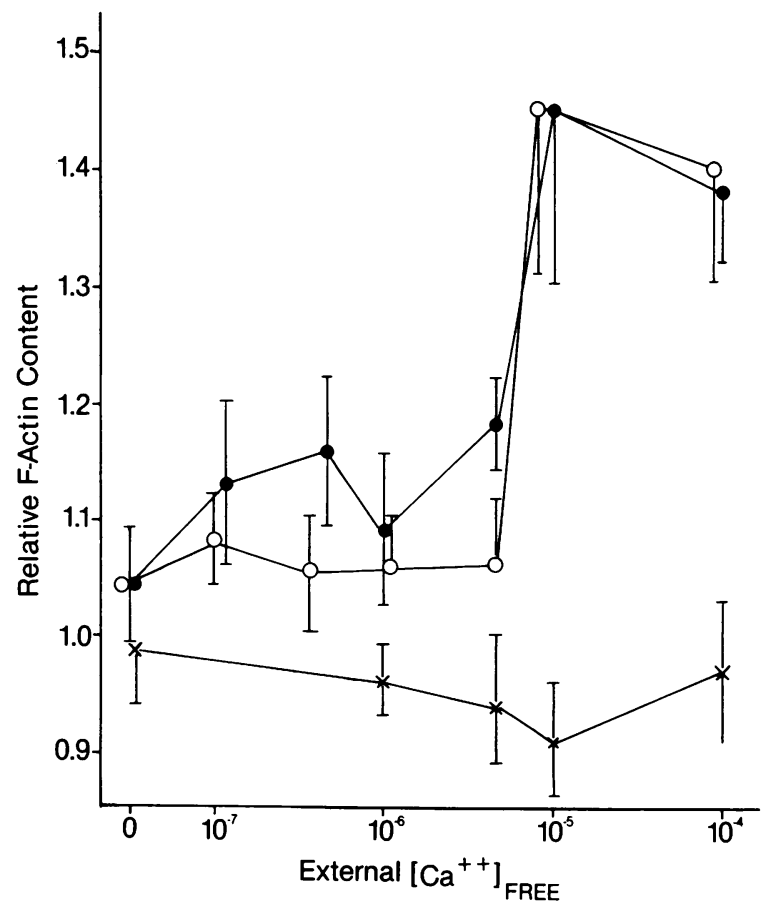

Figure 5. Effect of $\left[\mathrm{Ca}^{2+}\right]_{\text {free }}$ on F-actin content of A23187-activated neutrophils. Cells were exposed to $1 \mu \mathrm{M}$ A23187 as described in Fig. 4. The values plotted are the mean \pm SD for five trials at $5 \mathrm{~s}(-\times-)$, $1.0 \mathrm{~min}(-\bullet-)$ and $1.5 \mathrm{~min}(-0-)$ after addition of A23187 in the indicated $\left[\mathrm{Ca}^{2+}\right]_{\text {free }}$. The 0 point refers to DMSO $(0.05 \mathrm{vol} \%)$ value at the indicated time. 
and PMA simultaneously or serially on F-actin content of neutrophils. We determined the effect of exposing neutrophils in $>10^{-5} \mathrm{M}\left[\mathrm{Ca}^{2+}\right]_{\text {free }}$ or $10^{-7} \mathrm{M}\left[\mathrm{Ca}^{2+}\right]_{\text {free }}$ to either PMA or A23187 or a combination of PMA and A23187 simultaneously. The results are shown in Table II. F-actin content was determined at the time of expected maximum F-actin content. The results suggest that PMA blocks the A23187-activated increase in Factin content observed at $\geq 10^{-5} \mathrm{M}\left[\mathrm{Ca}^{2+}\right]_{\text {free }}$. The F-actin content observed following simultaneous A23187 and PMA addition is much less than that observed with $f$ MLP. Simultaneous activation with PMA and A23187 in the presence of $10^{-7} \mathrm{M}$ $\left[\mathrm{Ca}^{2+}\right]_{\text {free }}$ does not cause a change in $\mathrm{F}$-actin content that is significantly different from that induced by A23187 or PMA alone. Table III shows the effect of pre-activation of neutrophils with A23187 or PMA on the subsequent A23187- or PMA- and $f$ MLP-induced changes in F-actin content. In these experiments, neutrophils in $\geq 10^{-5} \mathrm{M}\left[\mathrm{Ca}^{2+}\right]_{\text {free }}$ were preincubated in $0.1 \mu \mathrm{M}$ PMA or $1 \mu \mathrm{M} \mathrm{A23187}$ for $10 \mathrm{~min}$ and then activated with A23187 or PMA or $f$ MLP. F-actin content was determined at the time of expected maximum F-actin content for the second stimulant. As shown in Table III, preincubation of cells with PMA limited the subsequent A23187-induced, but not the $f$ MLP-induced, increase in F-actin content. The final F-actin content with A23187 activation resembles that with PMA alone. Also, as shown in Table III reversal of the sequence of addition, i.e., PMA activation following A23187 preincubation, did not alter F-actin content above that expected with PMA alone and the combined effects of A23187 and PMA on F-actin content were not additive. $f$ MLP-induced polymerization in cells preincubated with A23187 was not changed. Since fMLP induces significant actin polymerization in cells preincubated with either PMA or A23187, this indicates that the actin is able to polymerize. Since either combining PMA with A23187 or PMA preincubation limits the expected A23187 induced polymerization, this suggests that either the extent or the kinetics of A23187induced polymerization are altered by PMA. To examine this point, we determined the time course of F-actin content in cells preincubated with PMA and then activated with A23187. As shown in Fig. 6, preincubation of cells with PMA inhibits the A23187-induced actin polymerization in neutrophils. These results show that combinations of A23187 with PMA do not mimic $f$ MLP-induced polymerization and PMA blocks A23187-induced polymerization in neutrophils.

Table II. Simultaneous Combination of A23187, $P M A$, and $f M L P$ at Varied $\left[\mathrm{Ca}^{2+}\right]_{\text {free }}$

\begin{tabular}{lll}
\hline Activator(s) & $210^{-5} \mathrm{M}\left[\mathrm{Ca}^{2+}\right]_{\text {mee }}$ & $10^{-7} \mathrm{M}\left[\mathrm{Ca}^{2+}\right]_{\text {troc }}$ \\
\hline DMSO (0.02\%) & $0.98 \pm 0.04$ & $0.99 \pm 0.03$ \\
$0.5 \mu \mathrm{M} f$ MLP & $1.75 \pm 0.10$ & $1.68 \pm 0.10$ \\
$1.0 \mu \mathrm{M}$ A23187 & $1.51 \pm 0.12$ & $1.06 \pm 0.03$ \\
$0.1 \mu \mathrm{M}$ PMA & $1.15 \pm 0.08$ & $1.20 \pm 0.10$ \\
$0.1 \mu \mathrm{m}$ PMA $+0.5 \mu \mathrm{M} f \mathrm{MLP}$ & $1.76 \pm 0.09$ & $\mathrm{ND}$ \\
$0.1 \mu \mathrm{M}$ PMA + $1.0 \mu \mathrm{M} \mathrm{A23187}$ & $1.18 \pm 0.07$ & $1.12 \pm 0.08$
\end{tabular}

Values are F-actin content \pm 1 SD from five trials and all values expressed relative to cells plus buffer for $60 \mathrm{~s}$. The DMSO is the solvent for all three activators. Time F-actin assayed after PMA $90 \mathrm{~s}, f$ MLP 60 s, A23187 75 s, DMSO 60 s, PMA $+f$ MLP $=75$ s, PMA

$+\mathrm{A} 23187=75 \mathrm{~s}$.

\section{Discussion}

The studies presented here compare the changes in F-actin content of neutrophils caused by activation with $f$ MLP, a calcium ionophore and PMA. The studies show that neither PMA or ionophore alone or in combination induce changes in F-actin content that mimic those caused by $f$ MLP. Specifically, the data demonstrates the following points: (a) Under conditions that maximize the effects of all three activators, the maximum extent of actin polymerization and the rate of polymerization are greater with $f$ MLP than with PMA or the $\mathrm{Ca}^{2+}$ ionophore; $(b)$ The effects of $f$ MLP and the $\mathrm{Ca}^{2+}$ ionophores are dose dependent and PMA effects occur at massive PMA concentrations; (c) The A23187induced changes in F-actin content, but not those caused by $f$ MLP, require external $\left[\mathrm{Ca}^{2+}\right]_{\text {free }}$ of at least $5 \mu \mathrm{M} ;(d)$ Combined activation with A23187 and PMA does not mimic $f$ MLP-induced polymerization; $(e)$ Preactivation of neutrophils inhibits A23187-induced but not $f$ MLP-induced actin polymerization in neutrophils. Since protein kinase $C$ activation is the major, though not the only effect of PMA on neutrophils, the results suggest that although protein kinase $C$ activation and increase of intracellular $\left[\mathrm{Ca}^{2+}\right]_{\text {free }}$ are early events in $f \mathrm{MLP}$-activated cells, neither event alone causes the $f$ MLP-induced polymerization or depolymerization of actin.

Several lines of experimental data suggest that either an increase in intracellular $\left[\mathrm{Ca}^{2+}\right]_{\text {free }}$ or activation of protein kinase $\mathrm{C}$ may cause the dramatic cytoskeletal reorganization that follows $f$ MLP binding to neutrophils. These include observations on the effect of $\left[\mathrm{Ca}^{2+}\right]_{\text {free }}$ on actin polymerization in vitro $(22,23)$, demonstration of the $\mathrm{Ca}^{2+}$-sensitive, actin regulatory protein, gelsolin, in neutrophils (18) and descriptions of the temporal relationship of protein kinase $\mathrm{C}$ activation and increase in intracellular $\left[\mathrm{Ca}^{2+}\right]_{\text {free }}$ to actin polymerization in $f$ MLP-stimulated neutrophils (11-13).

The $\left[\mathrm{Ca}^{2+}\right]_{\text {free }}$ dramatically affects the polymerization of actin in vitro. Kasai (22) demonstrated that nucleation of purified muscle actin is sensitive to $\left[\mathrm{Ca}^{2+}\right]_{\text {free }}$. Free $\left[\mathrm{Ca}^{2+}\right]$ in the nanomolar to millimolar range exhibit a triphasic effect on in vitro actin polymerization. Micromolar $\left[\mathrm{Ca}^{2+}\right]_{\text {free }}$ inhibits nucleation of actin (22) and decreases rate of polymerization while both nanomolar and millimolar $\left[\mathrm{Ca}^{2+}\right]_{\text {free }}$ promote nucleation and increase the rate of actin polymerization (23). Logically, therefore, a change in intracellular $\left[\mathrm{Ca}^{2+}\right]_{\text {free }}$ may be an important determinant of the state of actin polymerization in neutrophils. An effect of $\left[\mathrm{Ca}^{2+}\right]_{\text {free }}$ on polymerization could reflect a direct effect of $\mathrm{Ca}^{2+}$ on actin or an effect of $\mathrm{Ca}^{2+}$ mediated by gelsolin.

Gelsolin is a $92-\mathrm{kD}, \mathrm{Ca}^{2+}$-sensitive, actin regulatory protein described by Yin et al. (19) that in the presence of $1 \mu \mathrm{M}\left[\mathrm{Ca}^{2+}\right]_{\text {free }}$ has several effects on actin polymerization in vitro (19-21). This protein could mediate calcium-dependent changes in cytoskeletal organization in the cell. Based upon current data, it is unlikely that $f$ MLP-induced actin polymerization is caused by $\mathrm{Ca}^{2+}$-activation of gelsolin because $f$ MLP-induced polymerization occurs at the barbed end of filaments and is cytochalasin sensitive $(4,5)$, while in vitro, gelsolin-induced polymerization occurs at the pointed end of actin filaments (21). In spite of this theoretical argument, recent studies of gelsolin-actin interactions in $f$ MLPactivated macrophages show that in vitro interactions of gelsolin and actin may differ from their in vivo interactions (32). These studies allow a possible role for gelsolin in actin polymerization or depolymerization in neutrophils. Specifically, Kurth et al. $(33,34)$ showed that in vitro, in the presence of $1 \mu \mathrm{M}\left[\mathrm{Ca}^{2+}\right]_{\text {free, }}$, 


\begin{tabular}{|c|c|c|c|c|}
\hline & $\begin{array}{l}\text { DMSO } \\
\text { Control }\end{array}$ & $\begin{array}{l}0.1 \mu \mathrm{M} \\
\text { PMA }\end{array}$ & $\begin{array}{l}1.0 \mu \mathrm{M} \\
\mathrm{A} 23187\end{array}$ & $\begin{array}{l}0.5 \mu \mathrm{M} \\
f \mathrm{MLP}\end{array}$ \\
\hline \multicolumn{5}{|c|}{ Activator added after 10 -min preincubation with } \\
\hline DMSO (0.01 vol \%) & $1.00 \pm 0.04$ & 一 & $1.48 \pm 0.06$ & $1.83 \pm 0.09$ \\
\hline $0.1 \mu \mathrm{M}$ PMA & $1.20 \pm 0.07$ & - & $1.19 \pm 0.07$ & $1.62 \pm 0.11$ \\
\hline \multicolumn{5}{|c|}{ Activator added after 10 -min preincubation with } \\
\hline DMSO (0.01 vol \%) & $0.98 \pm 0.03$ & $1.12 \pm 0.04$ & - & $1.75 \pm 0.09$ \\
\hline $1 \mu \mathrm{M} \mathrm{A23187}$ & $1.16 \pm 0.05$ & $1.20 \pm 0.06$ & - & $1.75 \pm 0.10$ \\
\hline
\end{tabular}

Values are F-actin content \pm 1 SD from five trials and all values are expressed relative to cells plus buffer incubated for 10 min. Time F-actin assayed after PMA $=90 \mathrm{~s}, \mathrm{~A} 23187=75 \mathrm{~s}, f \mathrm{MLP}=60 \mathrm{~s}, \mathrm{DMSO}=60 \mathrm{~s}$.

purified gelsolin forms an irreversible $130-\mathrm{kD}$ complex with actin; however, more recently Chaponnier et al. (32) showed that in macrophages the $130-\mathrm{kD}$ complex is reversible despite the presence of $\geq 1 \mu \mathrm{M}\left[\mathrm{Ca}^{2+}\right]_{\text {free }}$. Therefore, modification of gelsolin-actin interactions via calcium or as yet undefined mechanisms may allow a role for gelsolin in polymerization or depolymerization of actin in $f$ MLP-activated neutrophils.

Finally, since protein kinase $\mathrm{C}$ activation and increase in intracellular $\left[\mathrm{Ca}^{2+}\right]_{\text {free }}$ are among the earliest events that occur during signal transduction in $f$ MLP-activated neutrophils, their interposition between ligand binding and maximal F-actin content suggest that either may be the cause of actin polymerization (11-13). Change in cytosolic free calcium concentration may affect actin polymerization independently or by an effect on gelsolin as noted above. The mechanism whereby phosphorylations of substrates by protein kinase $\mathrm{C}$ might alter F-actin content is more speculative. However, it is clear that protein kinase $\mathrm{C}$ mediated phosphorylations are pivotal in regulating several other neutrophil functions (30).

Despite the logical argument that change in intracellular $\left[\mathrm{Ca}^{2+}\right]_{\text {free }}$ or protein kinase $\mathrm{C}$ activation may cause $f$ MLP-induced actin polymerization/depolymerization, the studies presented here show that stimulation of neutrophils with $\mathrm{Ca}^{2+}$ ionophore in the presence of $\mathrm{Ca}^{2+}$, with PMA concentrations that activate protein kinase $C$ or with A23187 and PMA in combination do not mimic $f$ MLP-induced cytoskeletal reorganization. The studies show that a minimal, nonsaturable effect of PMA on F-actin content is observed and that the $\left[\mathrm{Ca}^{2+}\right]_{\text {frec }}$ required for A23187-induced change in F-actin content exceeds the max-

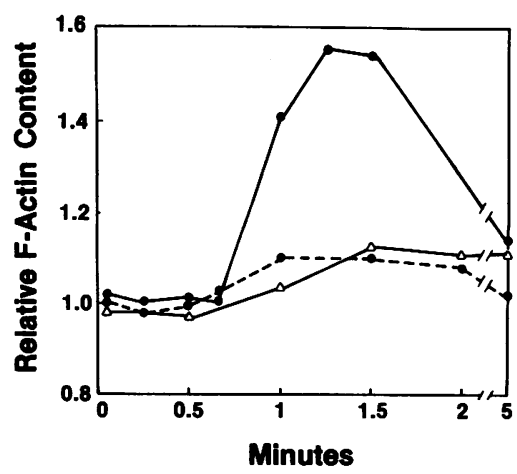

Figure 6. Effect of PMA preincubation on A23187-induced polymerization. Cells were exposed to $0.1 \mu \mathrm{M}$ PMA or control solvent (DMSO $0.01 \mathrm{vol} \%$ ) for $10 \mathrm{~min}$ at $25^{\circ} \mathrm{C}$. Then, $1 \mu \mathrm{M}$ A23187 was added to DMSO preincubated (- - ) or PMA preincubated cells (-- ---$)$ or $0.1 \mu \mathrm{M}$ PMA was added to DMSO

preincubated cells $(-\Delta-)$ and F-actin content was determined at the indicated times. Results are an example experiment. Values are expressed relative to cells preincubated with DMSO for $10 \mathrm{~min}$. imum intracellular $\left[\mathrm{Ca}^{2+}\right]_{\text {free }}$ reported with Quin 2, Indo 1, or Fura 2 in $f$ MLP-activated neutrophils $(11,12,31)$. Our studies with fixed, NBD-phallacidin stained neutrophils presented here are in agreement with the studies of Sklar et al. (17), Yassin et al. (24), and Sha'afi (34). In studies with Quin 2 buffering of calcium transients and measurement of cytoskeleton associated actin, these investigators suggest that an increase in intracellular calcium is neither necessary or sufficient to explain $f$ MLP-induced actin polymerization.

The studies presented here and earlier studies by Sha'afi (34) clearly suggest that PMA or $\mathrm{Ca}^{2+}$-dependent, $\mathrm{A} 23187$ activation of neutrophils alone or in combination do not mimic $f$ MLPinduced changes in F-actin content. However, significant differences in our observations with A23187 and those of Sha'afi (34) do exist. Specifically, while Sha'afi reports little effect of $\left[\mathrm{Ca}^{2+}\right]$ on A23187-induced change in the cytoskeleton-associated actin of operationally defined Triton insoluble cytoskeletons, the A23187-induced effects we observe clearly depend on external $\mathrm{Ca}^{2+}$ concentration. Previous work from our laboratory (6) suggests that cytoskeleton-associated actin measured by gels and F-actin content as determined by NBD-phallacidin extraction may not be identical. The reason for the differences in $\mathrm{Ca}^{2+}$ dependence is not clear; however, cytoskeleton-associated actin in operationally defined Triton insoluble cytoskeletons is clearly affected by $\mathrm{Ca}^{2+}$-dependent proteolysis in the system used by Sha' afi (34). Further studies are necessary to resolve these differences. However, regardless of these differences, both investigators' results clearly show that PMA activation or $\mathrm{Ca}^{2+}$-dependent, A23187 activation of neutrophils alone or in combination do not mimic the $f$ MLP-induced changes in the state of actin polymerization. Furthermore, the results show that PMA preactivation blocks A23187-induced but not $f$ MLP-induced polymerization. These results suggest that neither protein kinase $\mathrm{C}$ activation alone nor increase in cytosolic $\left[\mathrm{Ca}^{2+}\right]_{\text {free }}$ are responsible for $f$ MLP-induced actin polymerization.

\section{References}

1. Sklar, L., A. Jesaitis, and E. Painter. 1984. The neutrophil Nformyl peptide receptor. Dynamics of ligand-receptor interactions and their relationship to cellular responses. In Contemporary Topics in Immunobiology. R. Synderman, editor. Plenum Publishing Corp., New York 24.

2. Schiffman, E., E. Corcoran, and S. Wahl. 1975. N-formyl methionyl peptides as chemoattractants for leukocytes. Proc. Natl. Acad. Sci. USA. 72:1059.

3. Howard, T. H., and W. H. Meyer. 1984. Chemotactic peptide 
modulation of actin assembly and locomotion in neutrophils. J. Cell Biol. 98:1265-1271.

4. Wallace, P., R. Wersto, C. Packman, and M. Lichtman. 1984. Fmet-leu-phe induces reversible changes in F-actin content of human blood neutrophils. J. Cell Biol. 99:1060-1965.

5. Howard, T. H., and C. O. Oresajo. 1985. The kinetics of chemotactic peptide-induced change in $\mathrm{F}$-actin content, $\mathrm{F}$-actin distribution and the shape of neutrophils. J. Cell Biol. 101:1078-1085.

6. Howard, T. H., and C. O. Oresajo. 1985. A method for quantifying F-actin in chemotactic peptide activated neutrophils. Study of effect of tBOC peptide. Cell Motil. 5:545-557.

7. Cockroft, S. J., J. Bonnet, and B. Gomports. 1980. Stimulus-secretion coupling in rabbit neutrophils is not mediated by phosphotidylinositol breakdown. Nature (Lond.) 288:275-277.

8. Serhan, C., J. Brockman, H. Korchak, A. Marcus, and G. Weissman. 1982. Endogenous phospholipid metabolism in stimulated neutrophils. Differential activation by $f$ MLP and PMA. Biochem. Biophys. Res. Commun. 107:951-958.

9. Volpi, M., R. Yassin, P. Naccache, and K. Sha'afi. 1983. Chemotactic factor causes rapid decreases in phosphotidylinositol, 4,5-biphosphate and phosphotidylinositol 4-monophosphate in rabbit neutrophils. Biochem. Biophys. Res. Commun. 112:957-964.

10. Dougherty, R., P. Godfrey, P. Hoyle, J. Putney, and R. Freer. 1984. Secretagogue-induced phosphoinositide metabolism in human leukocytes. Biochem. J. 222:307-314.

11. Korchak, H., K. Vienne, and G. Weissmann. 1984. Stimulus response coupling in the human neutrophil. II. Temporal analysis of changes in cytosolic calcium and calcium efflux. J. Biol. Chem. 259: 4076-4082.

12. Lew, D., C. Wollheim, F. Waldvogel, and T. Pozzan. 1984. Modulation of cytosolic-free calcium transients by changes in intracellular buffering capacity. Correlation with exocytosis and $\mathrm{O}_{2}$ production in human neutrophils. J. Cell Biol. 99:1208.

13. Schneider C., M. Zanetti, and D. Romeo. 1981. Surface-reactive stimuli increases protein phosphorylation in human neutrophils. $F E B S$ (Fed. Eur. Biochem. Soc.) Lett. 127:4-8.

14. Nishizuka, Y. 1984. The role of protein kinase $C$ in cell surface signal transduction and tumour production. Nature (Lond.). 308:693698.

15. Berridge, M. J. 1984. Inositol triphosphate and diacylglycerol as second messengers. Biochem. J. 220:345-360.

16. Sklar, L., G. Omann, and R. Painter. 1985. Relationship of actin polymerization and depolymerization to light scattering in human neutrophils. Dependence on receptor occupancy and intracellular $\mathrm{Ca}^{++} . J$. Cell Biol. 101:1161-1166.

17. Yin, H. L., J. Albrecht, and T. Stossel. 1981. Identification of gelsolin, a $\mathrm{Ca}^{++}$-dependent regulating protein of actin gel-sol transformation and its intracellular distribution in a variety of cells and tissues. J. Cell Biol. 91:901-906.

18. Yin, H., and T. Stossel. 1979. Control of cytoplasmic actin gelsol transformation, a calcium-dependent regulatory protein. Nature (Lond.). 281:583-586.

19. Yin, H., K. Zaner, and T. Stossel. $1980 . \mathrm{Ca}^{++}$control of actin gelation. Interaction of gelsolin with actin filaments and regulation of actin gelation. J. Biol. Chem. 255:9494-9500.
20. Yin, H., J. Hartwig, K. Maruyama, and T. Stossel. 1981. $\mathrm{Ca}^{++}$ control of actin filament length. Effects of macrophage gelsolin on actin polymerization. J. Biol. Chem. 256:9693-9696.

21. Kasai, M., S. Asakura, and F. Oosawa. 1962. The G-F equilibrium in actin solutions under various condition. Biochim. Biophys. Acta. 57: 13-21.

22. Dankert, P., and I. Low. 1977. Dual effect of $\mathrm{Ca}^{++}$on ultimate ATPase activity and polymerization of muscle actin. Biochim. Biophys. Acta. 484:169-176.

23. Yassin, R., J. Shofeyk, J. White, W. Tao, M. Volpi, T. Molski, P. Naccache, M. Feinstein, and R. Sha'afi. 1985. Effects of chemotactic factors and other agents on the amounts of actin and a 65,000 mol. wt. protein associated with the cytoskeleton of rabbit and human neutrophils. J. Cell Biol. 101:182-188.

24. Helfman, D., B. Applebaum, W. Vogler, and J. Kuo. 1983. Phospholipid sensitive $\mathrm{Ca}^{++}$-dependent protein kinase and its substrates in human neutrophils. Biochem. Biophys. Res. Commun. III:847-853.

25. Niedel, J., L. Kuhn, and G. Vandenbark. 1983. Phorbol ester receptor copurifies with protein kinase C. Proc. Natl. Acad. Sci. USA. $80: 36-40$

26. Boyum, A. 1968. Isolation of mononuclear cells and granulocytes from human blood. Scand. J. Clin. Lab. Invest. 97(Suppl. 21):77-85.

27. Kembold, C., C. Hai, and R. Murphy. 1985. Myoplasmic $\mathrm{Ca}^{++}$ and activation of vascular smooth muscle. In Advances in Protein Phosphatases II. W. Merlevede and J. Disalvo, editors. Leuven University Press, Leuven, Netherlands. 89-101.

28. Fabiato, A., and F. Fabiato. 1979. Calculatory programs for computing the composition of the solutions containing multiple metals and ligands used for experiments in skinned muscle cells. J. Physiol. (Paris). 75:463-505.

29. DiVirgilio, F., D. Lew, and T. Pozzan. 1984. Protein kinase C activation of physiological processes in human neutrophils at vanishingly small cytosolic $\mathrm{Ca}^{++}$levels. Nature (Lond.). 310:691-693.

30. Lazarri, K., P. Proto, and E. Simons. 1985. Cytoplasmic $\mathrm{Ca}^{++}$ concentrations peak within $10 \mathrm{sec}$ of neutrophil stimulation, preceding maximal depolarization and oxidative burst. Blood. 66(Suppl. 1):89a.

31. Chapionnier, C., H. Yin, and T. Stossel. 1985. Reversible actingelsolin complex formation in macrophages. J. Cell Biol. 101:136a.

32. Kurth, M., and J. Bryon. 1984. Platelet activation induces the formation of a stable gelsolin-actin complex from monomeric gelsolin. J. Biol. Chem. 259:7473-7479.

33. Bryan, J., and M. Kurth. 1984. Actin-gelsolin interactions. Evidence for two actin-binding sites. J. Biol. Chem. 259:7480-7487.

34. Sha'afi, R., J. Shefcyk, R. Yassin, T. F. P. Molski, M. Volpi, P. H. Naccache, J. R. White, M. B. Feinstein, and E. L. Becker. 1986. Is a rise in intracellular concentration of calcium necessary or sufficient for stimulated cytoskeletal-associated actin? J. Cell Biol. 102:1459.

35. Dale, M., and A. Penfield. 1984. Synergism between phorbol ester and A23187 in superoxide production by neutrophils. FEBS (Fed. Eur. Biochem. Soc.) Lett. 175:170-172.

36. Robinson, J., J. Bawdey, M. Karnovsky, and M. Karnovsky. 1984. Superoxide release by neutrophils: Synergistic effects of two phorbol ester and calcium ionophore. Biochem. Biophys. Res. Commun. 122: 734-739. 